\title{
Apolipoprotein AI Transgene Corrects Apolipoprotein E Deficiency-induced Atherosclerosis in Mice
}

\author{
Chris Pászty, ${ }^{*}$ Nobuyo Maeda, ${ }^{\star}$ Judy Verstuyft, ${ }^{\star}$ and Edward M. Rubin* \\ *Life Sciences Division, Lawrence Berkeley Laboratory, University of California, Berkeley, California 94720; \\ and ${ }^{\ddagger}$ Department of Pathology, University of North Carolina, Chapel Hill, North Carolina 27599
}

\begin{abstract}
Apolipoprotein E (apo E)-deficient mice are severely hypercholesterolemic and develop advanced atheromas independent of diet. The C57BL/6 strain differs from most inbred strains by having lower HDL concentrations and a high risk of developing early atherosclerotic lesions when fed an atherogenic diet. The relative HDL deficiency and atherosclerosis susceptibility of the C57BL/6 strain are corrected with the expression of a human apolipoprotein AI (apo AI) transgene in this genetic background. To examine if increases in apo AI and HDL are also effective in minimizing apo $\mathbf{E}$ deficiency-induced atherosclerosis, we introduced the human apo AI transgene into the hypercholesterolemic apo E knockout background. Similar elevations of total plasma cholesterol occurred in both the apo $\mathbf{E}$ knockout and apo $\mathbf{E}$ knockout mice also expressing the human apo AI transgene. The latter animals, however, also showed a two- to threefold increase in HDL and a sixfold decrease in susceptibility to atherosclerosis. This study demonstrates that elevating the concentration of apo $\mathrm{AI}$ reduces atherosclerosis in apo $\mathbf{E}$ deficient-mice and suggests that elevation of apo AI and HDL may prove to be a useful approach for treating unrelated causes of heightened atherosclerosis susceptibility. ( $J$. Clin. Invest. 1994. 94:899-903.) Key words: atherogenesis • transgenic mice • high density lipoproteins • lipoproteins
\end{abstract}

\section{Introduction}

Cardiovascular disease remains the chief cause of death in affluent nations (1), and atherosclerosis accounts for the majority of these deaths. The common forms of atherosclerotic heart disease are the result of the interactions of multiple genetic and environmental factors (2). The mouse has been used increasingly as a model system to study the genetics of atherosclerosis (3-9) because of the availability of both classical and modern genetic approaches for studying this complex disorder in a manner not possible in humans. Atherosclerosis susceptibility in

Address correspondence to Edward M. Rubin, Life Sciences Division, Lawrence Berkeley Laboratory, University of California, Berkeley, CA 94720.

Received for publication 18 January 1994 and in revised form 11 April 1994.

J. Clin. Invest.

(C) The American Society for Clinical Investigation, Inc.

0021-9738/94/08/0899/05 $\$ 2.00$

Volume 94, August 1994, 899-903 inbred strains of mice (10), as defined by the development of aortic lipid deposits after a dietary insult, results from the interaction of multiple genes. Several murine atherosclerosis susceptibility loci have been mapped (11-13), although no specific genes or gene products have yet been identified.

The C57BL/6 inbred strain of mice is susceptible to dietinduced atherosclerosis and, unlike resistant inbred strains of mice, has a significantly lower HDL concentration when fed an atherogenic diet. In addition, males and females of this strain respond differently to an atherogenic diet: females are more susceptible to atherosclerosis and have lower HDL levels than males (14). It was these two observations that implicated low HDL as a possible cause of the increased susceptibility to atherosclerosis found in the C57BL/6 strain. Recent studies in genetically engineered C57BL/6 mice have examined whether increasing the concentration of $\mathrm{HDL}$ in these mice could render them resistant to diet-induced atherosclerosis. In these studies, the (human) apo AI gene, a major determinant of HDL concentration, was introduced and expressed in this inbred strain (15). The increase in HDL levels in the apo AI transgenic mice was accompanied by a dramatic reduction in susceptibility to dietinduced atherosclerosis $(5,7)$.

apo E knockout (apo E KO) ${ }^{1}$ mice, derived from embryonic stem cells in which the murine apo $\mathrm{E}$ gene had been inactivated via gene targeting, has provided a new murine model for studying atherosclerosis susceptibility $(16,17)$ that does not require a dietary insult. These animals lack apo $\mathrm{E}$, a critical ligand in receptor-mediated removal of nearly all classes of lipoproteins, and have massive hypercholesterolemia, even when fed a low fat, low cholesterol diet. The development of atherosclerosis in these animals is significantly more severe and rapidly progressive than that of C57BL/6 mice. Furthermore, the atherosclerotic lesions in apo $\mathrm{E} \mathrm{KO}$ mice are found throughout the animal's arterial tree, while in C57BL/6 mice they are localized primarily to the proximal aorta.

This study examines the impact of elevated HDL levels (due to high levels of human apo AI) on the severe atherosclerosis susceptibility in hypercholesterolemic (due to the absence of plasma apo E) mice. In these studies, the human apo AI transgene was bred into the apo E KO background, which resulted in mice hemizygous for the human apo AI transgene as well as homozygous for the inactivated murine apo $\mathrm{E}$ allele (apo AI/apo E KO mice). The apo E KO and apo AI/apo E KO animals were compared with regard to lipoprotein parameters and atherosclerosis susceptibility.

1. Abbreviations used in this paper: IDL, intermediate density lipoprotein; KO, knockout. 


\begin{tabular}{|c|c|c|c|c|c|c|c|c|c|c|c|}
\hline \multirow[b]{2}{*}{ Genotype } & \multirow[b]{2}{*}{ (n) } & \multirow[b]{2}{*}{ Sex } & \multicolumn{4}{|c|}{ Apolipoproteins* } & \multicolumn{4}{|c|}{ Cholesterol $^{\ddagger}$} & \multirow{2}{*}{$\begin{array}{c}\text { Atherosclerosis* } \\
\begin{array}{c}\text { Mean lesion area/ } \\
\text { section }\left(\mathrm{mm}^{2}\right)\end{array}\end{array}$} \\
\hline & & & $\begin{array}{c}\text { Murine } \\
\text { apo E }\end{array}$ & $\begin{array}{l}\text { Murine } \\
\text { apo AI }\end{array}$ & $\begin{array}{l}\text { Human } \\
\text { apo AI }\end{array}$ & $\begin{array}{c}\text { Total } \\
\text { apo AI }\end{array}$ & HDL & $\begin{array}{l}\text { Non- } \\
\text { HDL }\end{array}$ & Total & $\begin{array}{c}\mathrm{HDL} / \\
\text { total }\end{array}$ & \\
\hline $\mathrm{AI} / \mathrm{E} \mathrm{KO}$ & (27) & $M+F$ & 0 & $8(1)^{\|}$ & $82(8)^{\prime \prime}$ & $90(9)^{\|}$ & $101(3)^{\|}$ & 465 & $566(22)$ & 0.18 & $776(233)^{11}$ \\
\hline E KO & (34) & $\mathbf{M}+\mathbf{F}$ & 0 & $55(3)$ & 0 & $55(3)$ & $31(2)$ & 447 & $478(22)$ & 0.07 & $5002(924)$ \\
\hline $\mathrm{AI} / \mathrm{E} \mathrm{KO}$ & (10) & F & 0 & $10(1)^{11}$ & $68(8)^{\prime \prime}$ & $78(9)^{11}$ & $102(4)^{\| \prime}$ & 452 & $554(50)$ & 0.18 & $1015(484)^{\prime \prime}$ \\
\hline E KO & (21) & $\mathbf{F}$ & 0 & $52(2)$ & 0 & $52(2)$ & $28(2)$ & 419 & $447(23)$ & 0.06 & $6612(1317)$ \\
\hline $\mathrm{AI} / \mathrm{E} \mathrm{KO}$ & (17) & $\mathbf{M}$ & 0 & $6(0.5)^{\|}$ & $93(13)^{\|}$ & $100(13)^{1}$ & $100(4)^{\| \prime}$ & 474 & $574(20)$ & 0.18 & $611(218)^{\|}$ \\
\hline E KO & (13) & $\mathbf{M}$ & 0 & $60(5)$ & 0 & $60(5)$ & $36(4)$ & 491 & $527(40)$ & 0.07 & $2498(517)$ \\
\hline C57BL/6 & (11) & $\mathbf{F}$ & $\mathrm{T} / \mathrm{C}$ & $107(2)$ & 0 & $107(2)$ & 49 & 20 & 69 & 0.70 & 0 \\
\hline
\end{tabular}

${ }^{\ddagger}$ The values shown represent the mean $( \pm$ SEM) in milligrams per deciliter for the number of animals $(n) . \quad *$ The values shown represent the mean ( \pm SEM) for the data set presented in Fig. 2. $\$$ The values shown represent the mean total cholesterol minus the mean non-HDL cholesterol in milligrams per deciliter. "Indicates significant differences $(P<0.005)$ between $\mathrm{AI} / \mathrm{E} \mathrm{KO}$ versus $\mathrm{E} \mathrm{KO}$ genotype groups. significant differences $(P<0.05)$ between $\mathrm{AI} / \mathrm{E} \mathrm{KO}$ versus $\mathrm{E} \mathrm{KO}$ genotype groups.

\section{Methods}

Animals. The human apo AI transgenic mice created in the C57BL/6 background have been described previously (15). The apo E KO mice originally made in the $129 /$ Ola background (18) were backcrossed to C57BL/6 for three generations. Mice homozygous for the human apo AI transgene were bred with apo E KO (87\% C57BL/6, 13\% 129/Ola) mice to produce offspring both hemizygous for apo $\mathrm{AI}$ and heterozygous for the apo E null allele. These were backcrossed to apo E KO mice to produce the apo AI/apo E KO and apo E KO littermates used in this study. Total cholesterol levels as well as the presence or absence of mouse apo $\mathrm{E}$ were used to distinguish apo $\mathrm{E}$ null allele heterozygotes from homozygotes $(16-18)$. Within the latter group, mice hemizygous for the human apo AI transgene were identified by the presence of human apo AI in their plasma. The genetic background of the apo $\mathrm{E}$ $\mathrm{KO}$ and apo AV/apo E KO mice used in this study was 90\% C57BL/6, $10 \%$ 129/Ola. Animals were fed Purina laboratory mouse chow (5001) containing $4.5 \%$ fat and $<0.03 \%$ cholesterol.

Apolipoproteins, lipoproteins, and lipids. Animals were fasted overnight, and blood was collected from the tail vein into tubes coated with EDTA. Total cholesterol was measured in saline with cholesterol reagent (High Performance Cholesterol Kit; Boehringer Mannheim Corp., Indianapolis, IN). HDL-cholesterol was measured after selective precipitation of non-HDL lipoproteins with polyethylene glycol (7) (Table I). Cholesteryl ester concentrations were determined indirectly from total cholesterol and free cholesterol levels (19). The levels of human apo AI and mouse apo AI were determined in transgenic mice by previously described radial-immuno diffusion assays (15). Absence or presence of mouse apo $\mathrm{E}$ was determined by ELISA using an anti-human apo $\mathrm{E}$ antibody (International Immunology Corp., Murrieta, CA) that crossreacts with mouse apo $\mathrm{E}$. For the determination of lipoprotein size, total lipoproteins $(d<1.21 \mathrm{~g} / \mathrm{ml})$ were isolated from plasma by ultracentrifugation at $d=1.21 \mathrm{~g} / \mathrm{ml}$ in a Beckman $42.2 \mathrm{Ti}$ rotor (Beckman Instruments, Inc., Fullerton, CA) $\left(40,000 \mathrm{rpm}, 15 \mathrm{~h}, 10^{\circ} \mathrm{C}\right)$ and were subjected to nondenaturing electrophoresis in $4-30 \%$ polyacrylamide gradient gels. Electrophoresed lipoproteins were stained with Coomassie R-250 and analyzed by scanning densitometry according to Nichols et al. (20), using coelectrophoresed molecular size calibrators to facilitate determination of lipoprotein particle sizes.

To determine lipoprotein subclass composition, plasma from apo AI/ apo $\mathrm{E} \mathrm{KO}$, apo $\mathrm{E} \mathrm{KO}$, and $\mathrm{C57B1} / 6$ mice was fractionated by sequential ultracentrifugation into VLDL/intermediate density lipoprotein (IDL) $(d$ $\leq 1.019)$, $\operatorname{LDL}(1.019 \leq d \leq 1.063)$, and $\operatorname{HDL}(1.063 \leq d \leq 1.20)$. Concentration of mouse apo AI, human apo AI, total cholesterol, and cholesteryl ester was determined for each fraction.

Histological analysis. Mice were killed, and hearts and aortas were fixed in $4 \%$ phosphate-buffered formaldehyde and then embedded in
$25 \%$ gelatin. For the quantitative analysis, the mean lesion area per section per animal was determined as described previously (15). We quantitated four $10-\mu \mathrm{m}$ aortic sections each separated by $80 \mu \mathrm{m}$. The first and most proximal section to the heart was taken $80 \mu \mathrm{m}$ distal to the point where the aorta first becomes rounded. The area of oil red $O$ staining fatty streak lesions in each section was determined using a calibrated eyepiece, and the mean lesion area per section per animal was calculated for each group of animals. The coded slides were examined blind in two separate analyses by the same examiner and gave consistent results $(r>0.92)$.

Statistical analysis. The significance of differences ( $P$ values) between means was tested by using the Mann-Whitney $U$ test for nonparametric analysis.

\section{Results}

Effects of apo $E$ and apo AI genotype on lipoproteins and apolipoproteins. Both the apo E KO and the apo AI/apo E KO mice had similarly elevated total cholesterol concentrations compared with that of the C57BL/6 control animals (Table I). The predominant lipoprotein class in the apo E KO and the apo AI/apo E KO mice was non-HDL cholesterol comprising very low density and low density lipoproteins (VLDL/IDL and LDL, respectively). The concentration of non-HDL cholesterol did not differ significantly between apo E KO and apo AI/apo E KO mice, but was over 20 -fold that of control C57BL/6 mice. HDL cholesterol levels were slightly lower in the apo E KO mice as compared with C57BL/6 mice, but were elevated two- to threefold in the apo AI/apo E KO mice. This elevation of HDL is consistent with several prior studies in transgenic mice $(15,21)$ and rats (22) demonstrating that elevation of human apo $\mathrm{AI}$ is accompanied by elevation of HDL in rodents. The ratio of HDL to total cholesterol was 0.70 in C57BL/6 control, 0.18 in apo $\mathrm{AI} / \mathrm{apo} \mathrm{E} \mathrm{KO}$, and 0.06 in apo E KO mice. Decreases in this ratio are associated with an increased risk for the development of atherosclerosis in both humans (23) and mice (24).

apo $\mathrm{AI}$ levels in the apo $\mathrm{E} \mathrm{KO}$ mice were approximately one-half those found in C57BL/6 mice. The apo AI/apo E KO mice had total apo AI (mouse and human) levels twofold higher than those found in apo E KO mice (Table I). It has been reported previously that in transgenic mice the high level expression of human apo $\mathrm{AI}$ is associated with profound reductions in the plasma levels of mouse apo $\mathrm{AI}(15,25)$. In the apo $\mathrm{AI} / \mathrm{apo} \mathrm{E} \mathrm{KO}$ mice, we observe a similar reduction (sevenfold) 
A

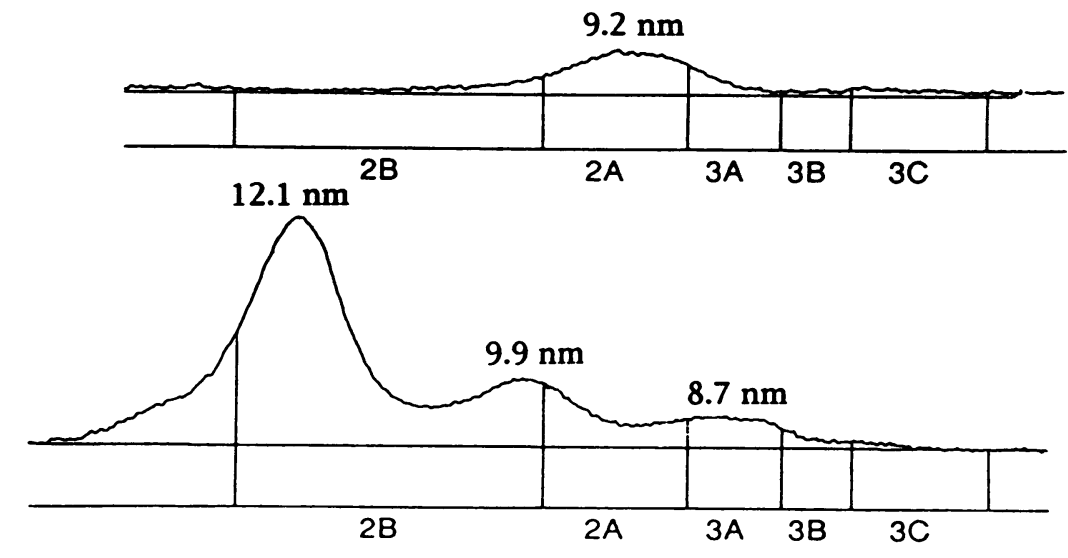

Figure 1. Distribution of HDL particle size subclasses. Plasma lipoproteins $(d<1.210$ $\mathrm{g} / \mathrm{ml}$ ) isolated from an apo $\mathrm{E} \mathrm{KO}$ mouse $(A)$ and an apo $\mathrm{AL} /$ apo $\mathrm{E} \mathrm{KO}$ mouse $(B)$ were subjected to nondenaturing PAGE to sizefractionate the high density lipoproteins. Sizing indices: $2 B(12.9-9.8 \mathrm{~nm}), 2 A(9.8-8.8$ $\mathrm{nm}), 3 A(8.8-8.2 \mathrm{~nm}), 3 B(8.2-7.8 \mathrm{~nm})$, and $3 C(7.8-7.2 \mathrm{~nm})$. in plasma levels of mouse apo $\mathrm{AI}$ as compared with apo $\mathrm{E} \mathrm{KO}$ mice.

The quantitative differences in apolipoproteins and lipoproteins found between the apo $\mathrm{E} \mathrm{KO}$, apo $\mathrm{AI} / \mathrm{apo} \mathrm{E} \mathrm{KO}$, and C57BL/6 control mice were similar whether the animals were compared grouped according to sex (i.e., female apo E KO versus female apo $\mathrm{AI} /$ apo $\mathrm{E} \mathrm{KO}$ ) or irrespective of sex (i.e., apo $\mathrm{E} \mathrm{KO}$ versus apo AI/apo E KO). Within any particular genotype, there were no significant differences found in apolipoproteins and lipoproteins between males and females.

Analysis of relative concentration and size distribution of VLDL and LDL particles was similar in the apo E KO and the apo AI/apo E KO mice (data not shown). However, HDL particle size distributions did differ between the apo $\mathrm{E} \mathrm{KO}$ and apo $\mathrm{AI} /$ apo $\mathrm{E} \mathrm{KO}$ mice (Fig. 1). In addition to increases in concentration, HDL from the apo AI/apo E KO mice demonstrated a polydispersity of particle sizes compared with the unidispersity in size of HDL from the apo E KO mice. This polydispersity of HDL size is consistent with prior analyses of HDL in mice expressing human apo AI transgenes $(15,25)$.

To examine the composition of the major lipoprotein subclasses, lipoproteins from apo $\mathrm{AI} /$ apo $\mathrm{E} \mathrm{KO}$, apo $\mathrm{E} \mathrm{KO}$, and C57BL/6 mice were separated by density gradient ultracentrifugation. Human apo AI, mouse apo AI, total cholesterol, and cholesteryl ester levels were determined for the HDL, LDL, and VLDL/IDL density fractions (Table II). The HDL fraction was found to contain $>75$ and $85 \%$ of the total apo AI in, respectively, the apo $\mathrm{E} \mathrm{KO}$ and the apo $\mathrm{AI} /$ apo $\mathrm{E} \mathrm{KO}$ mice. The small amount of apo AI found associated with the LDL and VLDL/IDL fractions in both the apo E KO and apo AV/apo $\mathrm{E} \mathrm{KO}$ mice is consistent with that reported previously for the apo E KO mice $(16,17)$.

In contrast to C57BL/6 mice, where most of the cholesterol and cholesteryl ester is found in the HDL fraction, in both the apo E KO and apo AI/apo E KO animals $80 \%$ of the cholesterol and cholesteryl ester is found in the VLDL/IDL fraction. The relative amounts of cholesterol among the different lipoprotein fractions separated by sequential ultracentrifugation (Table II) were consistent with the cholesterol values determined for the HDL and non-HDL fractions that were separated by polyethylene glycol precipitation (Table I).

Effects of apo $E$ and apo AI genotype on atherosclerotic lesion size. Highly significant differences in the area of fatty streak lesions in the proximal aorta were observed in the different groups of mice. Consistent with prior studies $(3,9)$, C57BL/ 6 mice do not develop aortic fatty streaks when fed mouse chow low in fat and cholesterol (Table I). In contrast, all the apo E KO mice $(n=23)$ fed the same chow diet developed significant fatty streak lesions (mean lesions $>1,000 \mu \mathrm{m}^{2} /$ section) by 12 wk of age (Fig. 2). Of the 22 apo AV/apo E KO mice studied, 16 had either no lesions or extremely small lesions (mean lesions $<1,000 \mu \mathrm{m}^{2} /$ section). The mean lesion area per section per animal of the apo AI/apo E KO mice was sixfold lower than that of the apo E KO mice $(P<0.0001)$ (Table I). C57BL/6 females have been shown previously to be more susceptible to diet-induced atherogenesis than male mice (14). In the present study, the females of the two different genotypes, apo AI/apo $\mathrm{E} \mathrm{KO}$ and apo E KO, also showed an increased susceptibility to atherogenesis when compared with males of the same genotype (Fig. 2). Comparisons of animals grouped by sex revealed that both females and males of the apo AI/apo E KO genotype had significantly $(P<0.05)$ smaller lesions than the same sex apo E KO mice.

Although as a group the apo AI/apo E KO mice had significantly higher total apo AI levels/HDL levels and significantly smaller lesion area than the apo E KO mice, on an individual animal basis there was no correlation $(r<0.41)$ within the apo $\mathrm{AI} / \mathrm{apo} \mathrm{E} \mathrm{KO}$ nor the apo E KO groups between apo AI levels/ HDL levels and lesion area.

Previous studies have shown that apo E KO mice examined

Table II. Lipoprotein Composition

\begin{tabular}{lcccr}
\hline \multicolumn{1}{c}{ Genotype } & $\begin{array}{c}\text { Mouse } \\
\text { apo AI }\end{array}$ & $\begin{array}{c}\text { Human } \\
\text { apo AI }\end{array}$ & $\begin{array}{c}\text { Total } \\
\text { cholesterol }\end{array}$ & $\begin{array}{c}\text { Cholesteryl } \\
\text { ester }\end{array}$ \\
\hline AI/E KO & & & & \\
$\quad$ HDL & 1.7 & 86.3 & 58.9 & 79.1 \\
LDL & 0.5 & 4.3 & 39.1 & 43.7 \\
VLDL/IDL & 2.1 & 8.5 & 396.6 & 461.1 \\
E KO & & & & \\
HDL & 39.3 & 0 & 24.6 & 32.1 \\
LDL & 3.4 & 0 & 33.7 & 37.7 \\
VLDL/IDL & 8.7 & 0 & 350.0 & 422.3 \\
C57BL/6 & & & & \\
HDL & 71.3 & 0 & 39.9 & 58.7 \\
LDL & 0 & 0 & 7.8 & 8.7 \\
VLDL/IDL & 0 & 0 & 3.6 & 2.6 \\
& & & & \\
\hline
\end{tabular}

Values (approximate serum concentrations) are measurements in milligrams per deciliter from pooled plasma. 


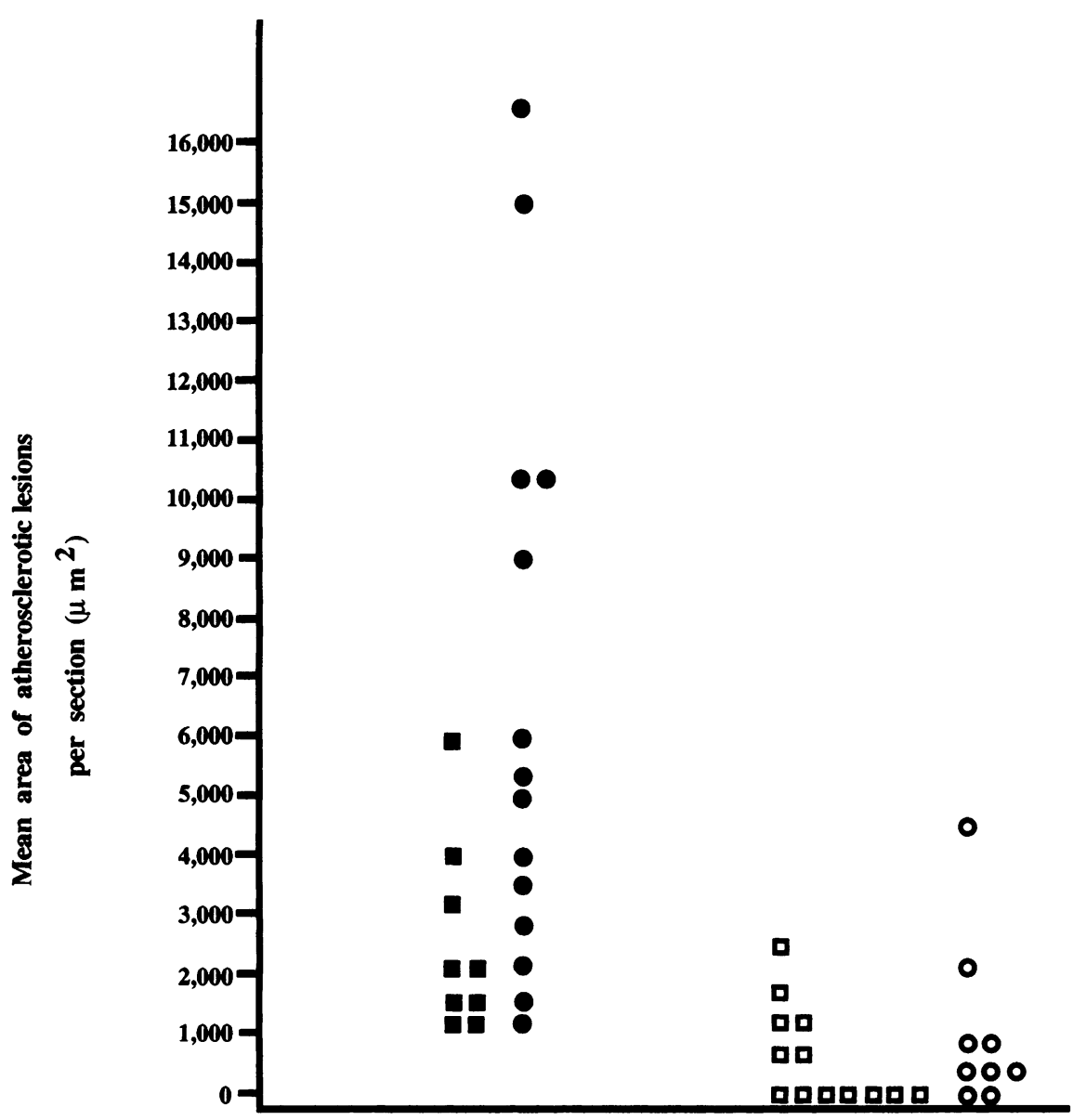

E-\%
AI E-/-
Figure 2. Mean lesion area. Each point represents the average area of luminal lipid staining material in four aortic sections from individual animals. The squares represent males, and the circles represent females. later in life $(6 \mathrm{mo})$, or after exposure to an atherogenic diet (high in fat and cholesterol), develop fibro-fatty lesions that share some features of advanced human atheromatous plaques $(16,17)$. The apo E KO and apo AI/apo E KO animals in this study were analyzed at a young age and exposed exclusively to diets low in fat and cholesterol. Despite this, many of the apo E KO animals had large lesions with extensive lipid-staining material infiltrating the disrupted media of the proximal aorta (data not shown). In contrast, the limited number of fatty streak lesions found in the apo $\mathrm{AI} / \mathrm{apo} \mathrm{E} \mathrm{KO}$ mice were smaller and did not extend into the media.

\section{Discussion}

Our results demonstrate that expression of the human apo AI transgene in apo E KO mice is associated with a reduction in the atherogenesis caused by the absence of a functional apo $\mathrm{E}$ gene. With regards to the murine genetic background, the apo $\mathrm{AI} /$ apo E KO and apo E KO littermates used in this study, although not genetically identical, had very similar genetic backgrounds (90\% C57BL/6, 10\% 129/Ola). This, coupled with the highly significant differences found in atherosclerosis susceptibility $(P<0.0001)$ and in HDL levels $(P<0.0001)$ between these two groups of mice, makes it extremely unlikely that these observed differences are simply due to segregating alleles of atherosclerosis susceptibility loci.
In comparison with the apo $\mathrm{E} \mathrm{KO}$ mice, the major apolipoprotein differences found in the apo $\mathrm{AI} / \mathrm{apo} \mathrm{E} \mathrm{KO}$ mice were: the presence of human apo AI, the increase in total apo AI levels, and the reduction of murine apo AI levels. In the apo AI/apo E KO animals, human apo AI comprises $>90 \%$ of the total apo AI. The analysis of apo AI distribution showed that the majority of apo AI in the two groups of animals was associated with the HDL fraction. Roughly similar minor amounts of apo AI were found in the non-HDL fractions of the apo AI/apo $\mathrm{E} \mathrm{KO}$ and apo E KO mice.

Coupled with the increase in total apo AI (primarily human) in the apo AI/apo E KO mice as compared with the apo E KO mice was the significant increase in $\mathrm{HDL}$ found in the apo $\mathrm{AV} /$ apo E KO animals. The non-HDL lipoprotein levels in the apo AI/apo E KO and the apo E KO mice were essentially the same. This implicates human apo AI containing HDL as the agent responsible for the greatly reduced incidence of atherosclerosis observed in apo AI/apo E KO mice as compared with apo E $\mathrm{KO}$ mice and is consistent with the previously reported decrease in diet-induced atherogenesis observed in apo AI transgenic C57BL/6 mice $(5,7)$.

The mechanisms by which the multiple genes involved in lipid transport affect atherosclerosis susceptibility have been only partially elucidated. An important property of apo E is its ability to participate in receptor-mediated clearance of lipoproteins from the blood. In its absence, cholesterol and triglyceride- 
rich lipoproteins accumulate in the blood resulting in increased deposition of lipids in the vasculature (26). Although the inverse relationship between $\mathrm{HDL}$ and apo $\mathrm{AI}$ concentrations and atherosclerosis risk has been recognized for decades $(27,28)$, the mechanism by which HDL lowers this risk is unclear. A hypothetical process, termed reverse cholesterol transport, remains the focus of the majority of studies aimed at understanding the protective nature of HDL. According to this model, circulating HDL accepts and participates in the removal of cholesterol from peripheral tissues, thereby preventing the accumulation of lipid in the walls of arteries. Based on this understanding, increases in HDL would tend to decrease the accelerated deposition of lipid in the vasculature resulting from an absence of apo E, consistent with the findings reported here.

In prior studies it has been demonstrated that elevation of apo $\mathrm{AI}$, and hence $\mathrm{HDL}$, reduced the risk of diet-provoked atherogenesis in a genetically susceptible (low HDL) strain of inbred mice (C57BL/6). The present study has extended these findings of reduced atherogenesis associated with increased apo $\mathrm{AI}$ and HDL, beyond the situation of HDL deficiency, to the setting of severe hypercholesterolemia-induced atherogenesis caused by the absence of apo $\mathrm{E}$.

These studies in mice, demonstrating that elevations of apo $\mathrm{AI}$ and HDL in different genetic and dietary milieus can dramatically reduce atherogenesis, suggest that elevation of these plasma constituents may prove to be a useful approach for treating unrelated causes of heightened atherosclerosis susceptibility.

Note added in proof. During the preparation of this manuscript we became aware of similar data demonstrating that human apo AI can protect against the development of atherosclerosis in an independently generated line of apo E-deficient mice (Breslow, J. L., personal communication).

\section{Acknowledgments}

We thank Charlotte Brown, Phil Cooper, Elaine Gong, and Pat Blanche for excellent technical assistance. We also thank Pat Donohue for excellent help in the preparation of this manuscript.

This work was supported by National Institutes of Health Grants (HL-42630 to N. Maeda and PPG HL-18574 to E. Rubin) and by a grant funded by the National Dairy Promotion and Research Board and administered in cooperation with the National Dairy Council. E. Rubin is an American Heart Association Established Investigator. Research was conducted at the Lawrence Berkeley Laboratory (Department of Energy Contract DE-AC0376SF00098), University of California, Berkeley.

\section{References}

1. Ross, R. 1986. Medical progress: the pathogenesis of atherosclerosis-an update. N. Engl. J. Med. 314:488-500.

2. Lusis, A. J., J. I. Rotter, and R. S. Sparkes. 1992. Molecular Genetics of Coronary Artery Disease. Karger, Basel. 453 pp.

3. Ishida, B. Y., and B. Paigen. 1989. Atherosclerosis in the mouse. In Genetic Factors in Atherosclerosis: Approaches and Model Systems. A. J. Lusis and S. R. Sparkes, editors. Karger, Basel. 189-222.

4. Lawn, R. M., D. P. Wade, R. E. Hammer, G. Chiesa, J. G. Verstuyft, and E. M. Rubin. 1992. Atherogenesis in transgenic mice expressing human apolipoprotein (a). Nature (Lond.). 360:670-672.

5. Rubin, E. M., R. M. Krauss, E. A. Spangler, J. G. Verstuyft, and S. M.
Clift. 1991. Inhibition of early atherogenesis in transgenic mice by human apolipoprotein AI. Nature (Lond.). 353:265-267.

6. Stoltzfus, L., and E. M. Rubin. 1993. Atherogenesis: insights from the study of transgenic and gene-targeted mice. Trends in Cardiovascular Medicine. 3:130134.

7. Schultz, J. R., J. G. Verstuyft, E. L. Gong, A. V. Nichols, and E. M. Rubin. 1993. Protein composition determines the anti-atherogenic properties of high density lipoproteins in transgenic mice. Nature (Lond.). 365:761-764.

8. Marotti, K. R., C. K. Castle, T. P. Boyle, A. H. Lin, and R. W. Murray. 1993. Severe atherosclerosis in transgenic mice expressing simian cholesteryl ester transfer protein. Nature (Lond.). 364:73-75.

9. Warden, C. H., C. C. Hedrick, J.-H. Qiao, L. W. Castellani, and A. J. Lusis. 1993. Atherosclerosis in transgenic mice overexpressing apolipoprotein A-II. Science (Wash. DC). 261:469-472.

10. Paigen, B., A. Morrow, C. Brandon, D. Mitchell, and P. Holmes. 1985. Variation in susceptibility to atherosclerosis among inbred strains of mice. Atherosclerosis. 57:63-73.

11. Paigen, B., D. Mitchell, K. Reue, A. Morrow, A. J. Lusis, and R. C. LeBoeuf. 1987. Ath-1, a gene determining atherosclerosis susceptibility and high density lipoprotein levels in mice. Proc. Natl. Acad. Sci. USA. 84:3763-3767.

12. Paigen, B., M. N. Nesbitt, D. Mitchell, D. Albee, and R. C. LeBoeuf. 1989. Ath-2, a second gene determining atherosclerosis susceptibility and high density lipoprotein levels in mice. Genetics. 122:163-168.

13. Stewart-Phillips, J. L., J. Lough, and E. Skamene. 1989. Ath-3, a new gene for susceptibility to atherosclerosis in mice. Clin. Invest. Med. 12:121-126.

14. Paigen, B., P. Holmes, D. Mitchell, and D. Albee. 1987. Comparison of atherosclerostic lesions and HDL-lipid levels in male, female, and testosteronetreated female mice from strains C57BL/6, BALB/c, and $\mathrm{C} 3 \mathrm{H}$. Atherosclerosis. 64:215-221.

15. Rubin, E. M., B. Y. Ishida, S. M. Clift, and R. M. Krauss. 1991. Expression of human apolipoprotein A-I in transgenic mice results in reduced plasma levels of murine apolipoprotein A-I and the appearance of two new high density lipoprotein size subclasses. Proc. Natl. Acad. Sci. USA. 88:434-438.

16. Plump, A. S., J. D. Smith, T. Hayek, K. Aalto-Setala, A. Walsh, J. G. Verstuyft, E. M. Rubin, and J. L. Breslow. 1992. Severe hypercholesterolemia and atherosclerosis in apolipoprotein E-deficient mice created by homologous recombination in ES cells. Cell. 71:343-353.

17. Zhang, S. H., R. L. Reddick, J. A. Piedrahita, and N. Maeda. 1992. Spontaneous hypercholesterolemia and arterial lesions in mice lacking apolipoprotein E. Science (Wash. DC). 258:468-471

18. Piedrahita, J. A., S. H. Zhang, J. R. Hagaman, P. M. Oliver, and N. Maeda 1992. Generation of mice carrying a mutant apolipoprotein $\mathrm{E}$ gene inactivated by gene targeting in embryonic stem cells. Proc. Natl. Acad. Sci. USA. 89:44714475 .

19. Allain, C. C., L. S. Poon, C. S. G. Chan, W. Richmond, and P. C. Fu. 1974. Enzymatic determination of total serum cholesterol. Clin. Chem. 20:470475.

20. Nichols, A. V., R. Krauss, and T. A. Musliner. 1986. Nondenaturing polyacrylamide gradient gel electrophoresis. In Methods in Enzymology: Plasma Lipoproteins. J. P. Segrest, and J. J. Albers, editors. Academic Press Inc., New York. 417-431.

21. Walsh, A., Y. Ito, and J. Breslow. 1989. High levels of human apolipoprotein A-I in transgenic mice result in increased plasma levels of small high density lipoprotein (HDL) particles comparable to human $\mathrm{HDL}_{3}$. J. Biol. Chem. 264:6488-6494.

22. Swanson, M. E., T. E. Hughes, I. St. Denny, D. S. France, R. Paterniti, Jr., C. Tapparelli, P. Gfeller, and K. Burki. 1992. High level expression of human apolipoprotein A-I in transgenic rats raises total serum high density lipoprotein cholesterol and lowers rat apolipoprotein A-I. Transgenic Research. 1:142-147.

23. Gordon, D. J., and B. M. Rifkind. 1988. High-density lipoprotein-the clinical implications of recent studies. N. Engl. J. Med. 32:1311-1316.

24. Marotti, K. R., C. K. Castle, R. W. Murray, E. F. Rehberg, H. G. Polites, and G. W. Melchior. 1992. The role of cholesteryl ester transfer protein in primate apolipoprotein A-I metabolism: insights from studies with transgenic mice. Arterioscler. Thromb. 12:736-744.

25. Chajek-Shaul, T., T. Hayek, A. Walsh, and J. L. Breslow. 1991. Expression of the human apolipoprotein A-I gene in transgenic mice alters high density lipoprotein (HDL) particle size distribution and diminishes selective uptake of HDL cholesteryl esters. Proc. Natl. Acad. Sci. USA. 88:6731-6735.

26. Mahley, R. W. 1988. Apolipoprotein E: cholesterol transport protein with expanding role in cell biology. Science (Wash. DC). 240:622-630.

27. Miller, N. E. 1987. Associations of high density lipoprotein subclasses with ischemic heart disease and coronary atherosclerosis. Am. Heart J. 113:589597.

28. Gofman, J. W., F. Lindgren, and H. Elliott. 1950. The role of lipids and lipoproteins in atherosclerosis. Science (Wash. DC). 11:166-171. 